\title{
Deictic shifts in fiction translation: Evidence of a more marked perspective in the translated narrative
}

\author{
Othman Ahmad Abualadas \\ Dept. of English Language and Literature, Faculty of Languages, University of Jordan-Aqaba, Aqaba 77110, Jordan
}

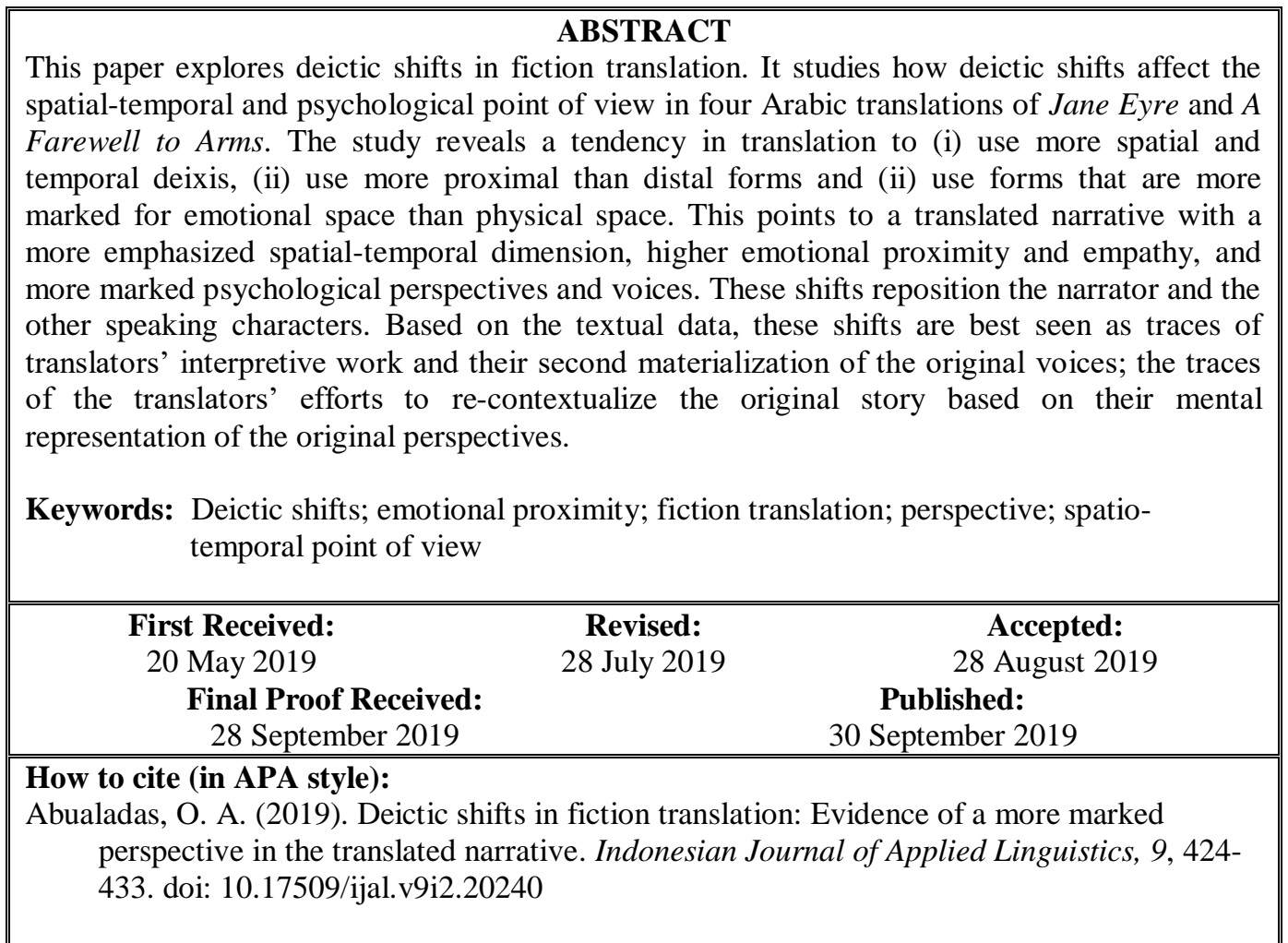

\section{INTRODUCTION}

This study is an empirical investigation of the systematic translational shifts in spatial and temporal deixis and their impact on the spatial-temporal viewpoint and psychological perspective adopted in the source text. Some previous empirical studies in this area have indicated some kinds of shift, such as a more subjective or objective rendering of deixis, a more approximated or distanced spatial-temporal point of view, a greater or lesser empathy in translation (e.g., Munday, 1997; Mason \& Şerban, 2003; Bosseaux, 2007; Goethals \& De Wilde, 2009). This line of research is still understudied in English-Arabic translated fiction. One of the very few empirical studies in this language pair is Abualadas (2015, see also 2018). His study, in a corpus of around 25,000 words selected from Wuthering Heights and their Arabic translations, finds an approximating pattern repositioning the main narrator.
The previous studies in this area have ignored some issues that could be of importance for describing the nature of the translational shift in both the spatialtemporal and psychological point of view. One issue is the differentiation between physical or emotional distance in the study of the shift and looking into which type is often more shifted through the translation process. Any empirical investigation into this issue may help characterize which aspects of the original point of view are more prone to shift in fiction translation. Another essential question that needs empirical investigation is from whose perspective the shift more often occurs (e.g., the narrator or the other speaking characters) or whether translations seem to prioritize one voice in the narrative over another during the decision-making process. Another issue that remains under-researched is when and why the shift in point of view occurs. There has been much focus in many previous studies on the potential effects of this shift in the original stylistic and narratological dimensions, 
while no or very little attention is paid to the translational processes underlying the resulting shift in the original perspective. The present study attempts to provide an answer to these questions.

\section{Time and place deixis: Definition}

According to Lyons (1977; 2005), deixis is the function of "pointing" or "indicating" to people or objects in the context in which utterances are used, and those lexical items that are used to fulfill this function, like "that", "this" and "they", are often termed "deictic expressions" or "deictics". The literature has identified a number of types of deictics, most prominently person deictics, spatial deictics and temporal deictics. Levinson (2006, pp. 114-118) states that spatial and temporal deictics are those that point to the different places and times referred to in the utterance. Spatial deictics indicate the location of referents in space. They reflect the viewing positions assumed by the speaker or the camera angles adopted in the text, as Simpson (1993, p. 11) points out. Spatial deictics basically include proximal and distal demonstratives like "this" and "that" and proximal and distal place adverbs such as "here" and "there". Temporal deictics show a temporal reference point relative to the utterance time, which is often reflected in the choice of verb tense (past, present or future) and time adverbs such as the proximal "now" and the distal "then".

\section{Spatial and temporal deictics in fictional texts: Point of view and empathy}

Spatial and temporal deictics are associated with a deictic field whose "origo" (zero ground) is the speaker's time and location at the time of speaking (Levinson, 2006, p. 111). Any utterance then takes place in a spatio-temporal context whose zero-point is "the here-and-now" (Lyons, 2005, p. 304). Spatial and temporal deictics may also be transposed to some other origo, such as a protagonist or character at a specific time and place in a fictional text. This is referred to as a "deictic shift", and this is what enables the reader to enter the fictional story worlds and to shift cognitively from one world to another (Segal, 2009, p. 74).

Spatial and temporal deictics not only establish the spatio-temporal point of view of the fictional text, but also help construct the "psychological point of view": the ways in which the story is mediated through the consciousness of the narrator, and which may affect the way the reader perceives the story (see Fowler, 1996, p. 120; Simpson, 2004, pp. 79-80). The choice between a proximal or distal deictic (e.g., "this event" or "that event") not only reflects physical proximity or distance between the speaker and the referent, but also may indicate emotional proximity or distance. This alteration between distal and proximal forms in a fictional text can indicate the narrator's sympathy or antipathy towards the referent or the narrated event and hence may reflect the level of his/her objectivity in narration. The spatial and temporal orientations in a fictional text are just one linguistic realization of the adopted psychological perspective. The beliefs and opinions of the medium through which the story is told may sometimes govern the type of spatial and temporal viewpoints adopted (Simpson, 1993, p. 19).

In fact, Lyons (1977, p. 677) referred to such use of spatial and temporal deictics as "empathetic use", the use that signals the extent to which a speaker or writer is personally engaged with the people or events he/she is referring to. Lyons (2005, pp. 310-311) also uses here the notion of "secondary deixis" to refer to such uses when the choice between a proximal and a distal can be clearly expressive, and whose expressivity is identified as that of emotional proximity or distance. If people refer or point at something physically close to them, they normally use the proximal "this", but if they use the distal "that", it may express their attitudinal dissociation from the thing they are referring to.

Following the work of Uspensky (1973), Fowler (1996, pp. 170-183) identifies two main psychological viewpoints that reflect two different positions that the narrator may occupy in narration. The first is the "internal" narratorial viewpoint, which is often restricted to the subjective perspective of a participating character, allowing for their personal thoughts and subjective evaluation of the story events and characters. The second is the "external" narratorial viewpoint, where the events are narrated from a perspective outside of the story world of any character, which may allow for more objective description and evaluation.

\section{Spatial and temporal deictics in fiction translation}

A number of studies have looked into the change in place and time deixis in translated fictional texts and its overall effects in the spatio-temporal framework of the original. In English translations of Romanian short stories, Mason and Şerban (2003) find a tendency to translate proximal deictics (e.g., "this day" and "here") by a distal (e.g., "that day" and "there") and to add extra distal deictics via translation, which suggests a distancing trend in translating spatial and temporal deictics. Mason and Şerban suggest that such a distancing trend may push the referent further away both in time and place from the speaker and lead to more alienation in the translated text compared to the original. Using Toolan's (1990) framework of analyzing deixis in narrative texts, Mason and Şerban argue that the use of such proximals as "this" and "now" in pasttense narration may reflect a level of narratorial engagement in or with the narrated event or referent. It may reflect the narrator's attempts to recreate the immediacy of the story events and to relive them, and which may call for reader participation with the mental or psychological state of the narrator. The distancing and alienating pattern found in translation can however point to a shift in the opposite direction: less participation on the part of the narrator and reader.

Using a computerized model, Bosseaux (2007) analyzes the shift in the time and place deictics "now" and "here" in French translations of an English novel. Bosseaux finds a tendency to omit these deictics in translation. She argues that this leads to a target text that is less deictically-marked than the original and may also 
affect the feel of the original text. She argues that the use of time and place deictics allows speakers to express their location in and through their utterances, so their loss in translation may lead to a narrator whose position in time and place is less emphasized. This indicates a translation with a less narratorial involvement compared to the original. But one limitation here is that the computerized model that Bosseaux uses gives a very decontextualized description of deictic shifts. Also, although the studies of Mason and Şerban (2003) and Bosseaux (2007) reveal significant trends of translational shift, they have avoided making any claims about the translational processes or assumptions underlying the shift.

In some other studies, the findings were unable to confirm any particular trend of shift. Goethals (2007) examines deictic shifts in a corpus of Dutch-Spanish translations, but the results were unable to confirm any distancing or approximating trend. The switches between distal and proximal forms have differed significantly between the different translations. Also, Goethals and De Wilde (2009), in a Spanish translation of a Dutch novel, have concluded that deictic shifts are not frequent or systematic, nor do they reflect a deliberate choice in translation. They have made an important claim here that such shifts may be better seen as "textual traces of the translator's interpretive process of resetting the spatiotemporal coordinates of the discourse" (Goethals \& De Wilde, 2009, p. 770).

Abualadas (2015, see also 2018) analyzes the shifts in different spatial and temporal deictics in a number of Arabic translations of Emily Brontë's Wuthering Heights. To allow for a more detailed qualitative and contextual description of the deictic shifts, he chooses a focused corpus; which involves approximately 25,000 words, and analyzes data manually. The findings indicate a trend (i) to add extra spatial and temporal deictics and (ii) change from a distal to proximal form in translation. This has suggested a target text that both (i) reveals more spatial and temporal settings than its original and (ii) reduces the distance between the main narrator and the story referents or events. Compared to the original, this trend of increasing the deictic anchorage and approximating the viewpoints has pointed to a greater subjectivity and engagement on the part of the narrator in the translated narrative. The study has a limitation that it pays much attention to the role of the narrator and ignores how the overall shift affects the voice of other speaking characters. Also, the study does not show which space (physical or emotive) is more affected by that approximating trend.

Abualadas (2015) argues that translational deictic shifts are often related to the translators' motivation for "explicitation" (Blum-Kulka, 2004, see Klaudy, 2009), which is related to their preference for clarity, and which may basically stem from a realization of their job as intercultural mediators (see Pápai 2004). But another limitation here is that these hypotheses remain only claims about possible motivations for the shift. Testing such hypotheses from an empirical standpoint can be quite challenging as it requires consideration of a wide range of contextual factors, such as, among others, attitudes, ideologies, cultural backgrounds, time and space limitations, and translation software used (Mason, 2000 , p. 17). Textual analysis may need to avoid speculating too much about the context and also avoid attributing particular motivation or intention in a confident manner to text producers since we have no access to their mental processes (Saldanha \& O'Brien, 2013, pp. 58-59).

\section{METHODS \\ Corpus}

The present study selects a corpus of approximately 60,000 words of running texts selected from two very popular classic novels published in English (where around 30,000 words are randomly picked from the first twenty chapters of each novel), along with two Arabic translations. The novels are the English classic Jane Eyre (1847) by the British novelist, Charlotte Brontë, and the American classic A Farewell to Arms by the American novelist Ernest Hemingway (1929). These novels are considered among the most read and taught English-Arabic translated fictional books in the Arab world.

The two selected novels show some similarity in their narrative point of view. Both are narrated in the first-person. The events are narrated from the perspective of their protagonist and most evaluations of events and characters are related through his/her subjective psychological perspective. Both in other words are related by a highly-involved narrator. However, the two novels show differences in their time periods, themes, and distinctive stylistic characteristics.

A Farewell to Arms is set in a village by the Italian-Austrian borders during the First World War. The novel revolves around "Frederic Henry", an American officer and ambulance driver with the Italian army, who fancies Catherine Barkley, a pretty British nurse. The events of the story are told from the perspective of its main protagonist, Frederic Henry. Ernest Hemingway in this novel uses a distinctive writing style. His style is often described as "lean, understated, evocative, spare, and without emotion" (Bloom, 2009, p. 31). Affected by his work as a journalist and reporter, he uses a journalistic style, with a tendency to use declarative sentences (subject-verbobject) that cast vividness and immediacy and provide visual presentation.

The vivid language he uses makes the reader take part in the story as intensely as Frederic Henry does: when you read the story, it is difficult not to imagine that you share with Henry the war events; "you are there when the shell strikes the dugout, on the brutal retreat from Caporetto, in the boat gliding over the dark waters of Lake Maggiore" (Berridge, 1984, p. 21). The representational language and painterly style Hemingway uses force the readers to connect and reflect on their own and without the narrator's intervention, 
and whatever emotions and feelings are evoked stem from their mental association with the drawn pictures and imagined scenes (Bloom, 2009, p. 31).

Jane Eyre is set in the rural Victorian England. It revolves around the story of a young orphan, Jane Eyre, who is raised by her aunt and who, after being mistreated and oppressed, starts her journey for salvation, and also whose continual quest for independence, dignity and love makes her achieve her goals. The story is narrated in the voice of its heroine, Jane Eyre, who, as a participant in the action, takes the reader step by step through her emotional journey and uses a style that is highly charged with her personal feelings and emotions, and often "feverish in its intensity" (Milton, 1984, p. 34). Charlotte Brontë uses stylistic features that intensify the psychological and moral involvement of the reader with her heroine. The whole novel was published at first as a real autobiography penned by a real person whose name is Jane Eyre, claiming that it is edited by "Currer Bell", the pseudonym that Charlotte Brontë uses to veil her real identity. Charlotte Brontë directly engages the reader and at times refers to him/her directly by using the expression "the reader". Her narrative is a "Bildungsroman", which recounts Jane's intellectual and emotional development and how she is shaped by her journey through different life difficulties and her responses to the challenges (Bloom, 2006, p. 19).

The present study has selected two available Arabic translations of each novel. The Arabic translations of A Farewell to Arms are Refat Nasim (1981) and Munir Baalbaki (2006a), while the translations of Jane Eyre are Helmi Morad (1998) and Munir Baalbaki (2006b). All translators are Arabic native speakers. Refat Nasim translated a number of English novels into Arabic. Munir Baalbaki and Helmi Morad translated many English literary works and are well-known in the Arab World for their significant contribution to the English-Arabic translated literature. So, the results of the present study can hopefully contribute to the study of their style in translation.

\section{Methodological issues}

The present paper uses a descriptive analytical model which compares the four translations with their originals to identify translational shifts. Since the study deals with emotional and psychological perspectives that are dynamic in nature, the process of analysis will be carried out manually, to allow for a rich contextualization of the shifts. The study will examine only optional ("non-obligator") shifts; which may indicate a (deliberate or non-deliberate) translation choice on the part of the translator, and will ignore the "obligatory" ones that often result from language constraints (Toury, 2012, p. 80). In contrast to English, Arabic deictic forms show for example greater gender and number distinctions, which often results in a greater grammatical explicitness in the English-Arabic translated text (see Klaudy, 2009). Such obligatory shifts, which often fall within the domain of contrastive linguistics, are often ignored by translation studies scholars.

\section{FINDINGS}

\section{Analysis of deictic shifts}

The study has compared the four translations with their original and identified 757 instances of shift in the translation of spatial and temporal deictics. These shifts can be classified into six categories:

1. insertion of new spatial or temporal deictics into the target text (e.g., translating "What are you doing?" into "What are you doing here?");

2. replacement of personal pronouns or a definite or indefinite article with spatial or temporal deictics (e.g., translating "She was not impressed by his story" into "She was not impressed by that story" or "the long barrels" into "these long barrels");

3. omission of spatial or temporal deictics without compensation (e.g., translating "There's no work now" into "There's no work");

4. replacement of spatial or temporal deictics with personal pronouns or a definite or indefinite article (e.g., translating "that move" into "her move" or "these troops" into "the troops");

5. replacement of a distal deictic item with a proximal (e.g., translating "that year" into "this year" or "that village" into "this village");

6. replacement of a proximal deictic with a distal (e.g., translating "look here" into "look there" or "I left the room now" into "I left the room then").

To draw a picture of the deictic shifts, to help describe the regularity of behaviour in the corpus, the distribution of the six categories of shift in the translations is given in Table 1 .

The deictic shifts in Table 1 suggest a shift towards three different directions. The first direction is towards adding spatial or temporal deixis in translation, which is realized by (i) inserting new spatial and temporal deictics and (ii) replacing personal pronouns and non-deictic expressions (i.e., definite/indefinite articles) with spatial and temporal deictics. The second direction is towards deleting spatial or temporal deixis, which is manifested by both (i) deleting spatial and temporal deictics without compensation and (ii) replacing spatial and temporal deictics with personal pronouns or non-deictic items (i.e., definite/indefinite articles). The third direction is towards replacing one form of deixis with another, which is brought about by the proximal-distal alternations.

First of all, the numerical data reveal that there are 418 shifts towards adding spatial or temporal deixis, 192 shifts towards shifting the deictic form (distalproximal), while 147 towards deleting spatial or temporal deixis, suggesting a trend to add rather than delete or shift the form of spatial or temporal deixis. This in other words indicates an orientation towards 
producing more spatial and temporal coordinates in the translated narrative compared to the original.

The deictic shifts in Table 1 can also indicate a shift towards either (i) distancing [+distance] or (i) approximating [-distance] the spatio-temporal viewpoint. The deictic shifts that point to distancing are: (i) inserting a new distal deictic, (ii) replacing a proximal form with distal and (iii) deleting a proximal deictic, without compensation or by replacing them with personal pronouns or definite and indefinite articles. The approximating shift takes place when (i) inserting a new proximal deictic, (ii) replacing a distal form with proximal and (iii) omitting a distal deictic, without compensation or by replacing them with other means such as personal pronouns and definite or indefinite articles. The numerical data in Table 2 indicate that, out of 757 deictic shifts, 538 shifts (about $71 \%$ of total shifts) suggest approximating, while only 219 shifts (about 29\%) suggest a shift in the opposite direction, distancing. This indicates that there is another orientation in translation towards using more approximated spatial and temporal viewpoints than in the original.

Table 1. Translational shifts in place and time deixis in the two novels

\begin{tabular}{|c|c|c|c|c|c|}
\hline \multirow[b]{2}{*}{ Type of shift } & \multicolumn{2}{|c|}{$\begin{array}{l}\text { A Farewell to Arms } \\
\text { Translations }\end{array}$} & \multicolumn{2}{|c|}{$\begin{array}{c}\text { Jane Eyre } \\
\text { Translations }\end{array}$} & \multirow[b]{2}{*}{ Total } \\
\hline & Nasim & Baalbaki & Morad & Baalbaki & \\
\hline inserting a new spatial or temporal deictic & 76 & 39 & 50 & 71 & 236 \\
\hline $\begin{array}{l}\text { replacing a personal pronoun or definite/indefinite article } \\
\text { with a spatial or temporal deictic }\end{array}$ & 39 & 60 & 31 & 52 & 182 \\
\hline deleting a spatial or temporal deictic without compensation & 22 & 11 & 19 & 7 & 59 \\
\hline $\begin{array}{l}\text { replacing a spatial or temporal deictic with a personal } \\
\text { pronoun or a definite/indefinite article }\end{array}$ & 37 & 15 & 25 & 11 & 88 \\
\hline replacing a distal deictic with a proximal & 10 & 40 & 29 & 47 & 126 \\
\hline replacing a proximal deictic with a distal & 14 & 29 & 11 & 12 & 66 \\
\hline
\end{tabular}

Table 2. Distancing [+distance] and approximating [-distance] shifts.

\begin{tabular}{lcccrr}
\hline & $\begin{array}{c}\text { A Farewell to Arms } \\
\text { Translations }\end{array}$ & \multicolumn{2}{c}{$\begin{array}{c}\text { Jane Eyre } \\
\text { Translations }\end{array}$} \\
\hline Distancing shifts [+distance] & Nasim & Baalbaki & Morad & Baalbaki & Total \\
inserting a new distal deictic & 17 & 36 & 37 & 14 & 104 \\
replacing a proximal form with distal & 14 & 29 & 11 & 12 & 66 \\
deleting a proximal deictic & 14 & 7 & 20 & 8 & 49 \\
Approximating shifts [-distance] & & & & & \\
\hline inserting a new proximal deictic & 98 & 63 & 44 & 109 & 314 \\
replacing a distal form with proximal & 10 & 40 & 29 & 47 & 126 \\
deleting a distal deictic & 45 & 19 & 24 & 10 & 98 \\
\hline
\end{tabular}

The following examples illustrate how shifts occur in their actual context and the way they affect the different viewpoints in the translated narrative. An English gloss of the Arabic translation is provided to enable non-Arabic readers to compare and trace the changes. For emphasis within examples, italic font is used. Underlining is used to indicate the English translated text.

1. Source Text (ST): "Do you know Mr. Rochester?" "No, I have never seen him."

"He is not resident, then?" (Jane Eyre, 1847, Ch. 12)

Target Text (TT): هو إذن لا يقيم هنا؟ (Baalbaki, p.186)

[Gloss: He then does not reside here?]

TT: إذن فهو لا يقيم هناك؟ (Morad, Volume 1, p.227)

[Gloss: So he does not reside there?]

2. ST: "I don't believe a word of this," Rinaldi said.

"Just as you like," Rocca said. "But I am telling it for our priest here." (A Farewell to Arms, 1929, Ch. 7)
TT: كما تريد. ولكني أروي هذه الحكاية لكاهننا.

(Baalbaki, p.57)

[Gloss: As you like. But I am narrating this story to our priest]

In Example (1), in their first encounter, Rochester does not inform Jane who he is (her new employer and the master of Thornfield) and he asks her whether Mr. Rochester lives in Thornfield. In the two Arabic texts, the addition of the proximal "here" and distal "there", which both refer to "Thornfield", indicates that there is spatial deictic knowledge being added via translation. Even if this added knowledge is not lexically or grammatically made explicit in the original story, it is actually inferable from the story context. In Example (2), from A Farewell to Arms, while dinning, a man named Rocca narrates a story about going to prison to help a priest there, and Henry's friend, Rinaldi, doubts his story. The translation replaces the personal pronoun "it" with the demonstrative phrase "this story". This is 
an instance of explicitation, which not only spells out the referent of the original, but also creates an act of verbal pointing to that referent. What the shift in both examples is simply indicating is a spatial dimension being added in the translated text.

Deictic shifts not only increase deictic knowledge, but also lead to more approximated point of view in the translated text:

3. ST: "You live just below-do you mean at that house with the battlements?" pointing to Thornfield Hall, ... (Jane Eyre, 1847, Ch. 12)

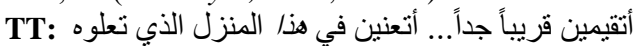

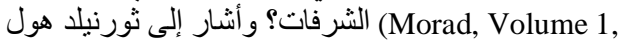
p.227)

[Gloss: You live nearby. Do you mean at this house with the battlements? pointing to Thornfield Hall]

4. ST: "There isn't any place," she said. She came back from wherever she had been. "We might sit there just for a little while."

We sat on the flat stone bench and I held Catherine Barkley's hand. (A Farewell to Arms, 1929, Ch.6)

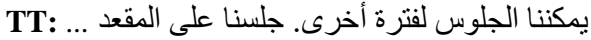
(Nasim, p.30)

[Gloss: We can sit for a while longer. We sat on the stone bench and I was still holding her hand]

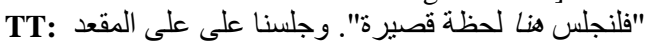

(Baalbaki, p.46)

[Gloss: Let us sit here for a short while. And we sat on the flat stone bench, and I held Catherine's hand]

5. ST: I hurried up the driveway and inside the reception hall I asked for Miss Barkley. (A Farewell to Arms, 1929, Ch.8)

TT: ثم عبرت ... مسرعاً, واتجهت فور وصولي إلى مكتب المدير

أين الآنسة باركلي? (Nasim, p.38)

[Gloss: I came in ... in a hurry, and then headed to the manager's office: Where is Miss Barkley?]

In Example (3), Rochester asks Jane where she is coming from and she replies "From just below", then he asks if she means Thornfield, a house nearby. Rochester here uses the distal "that" to refer to Thornfield, but the translation uses the proximal "this", which brings the referent "Thornfield" closer in the physical space to both Rochester and Jane. In Example (4), after being away at post for few days, Henry comes back to see Catherine, and he looks for a place where they can sit and chat. The distal "there" is dropped in the first translation while altered to its proximal correlate "here" in the second, which brings to the translated utterance spatial proximity that does not exist in the original.

In (5), on his way to the front, Henry stops the ambulance at the hospital to see Catherine. He says that he "asked for Miss Barkley" when he first arrived, but in the translation, the past tense is shifted into present, bringing the action closer in temporal space to the reader and conveying present "vividness" that does not exist in the original (see Toolan, 2016, pp. 134-136).
Deictic shifts may also impact the "psychological point of view" adopted in the original (Uspensky 1973, p. 81). This occurs most obviously when inserting extra proximals like "this" and "these" in translation and more importantly when substituting definite and indefinite articles with proximals. While a distal form like "that" is far on a scale of distance or proximity and a proximal like "this" is close, definite and indefinite articles are often unmarked or neutral in this regard (Levinson, 1983, pp. 82-83; Halliday and Matthiessen, 2004, pp. 212-213). In a narrative text, the selection of forms marked for proximity like "this" and "these" rather than forms unmarked for proximity like definite and indefinite articles can for instance express a sort of emotional involvement or empathy between the narrator and referent (Toolan, 1990, pp. 183-184).

6. ST: "Why did you not come and speak to me in the room?"

I thought I might have retorted the question on him who put it: but I would not take that freedom. (Jane Eyre, 1847, Ch. 17)

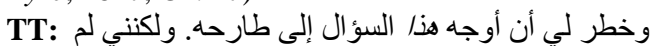
(Baalbaki, p.291)

[Gloss: I thought I would forward this question to the one who put it. But I did not dare to do so]

7. ST: "You have saved my life: I have a pleasure in owing you so immense a debt. I cannot say more. Nothing else that has being would have been tolerable to me in the character of creditor for such an obligation: ..." (Jane Eyre, 1847, Ch. 15)

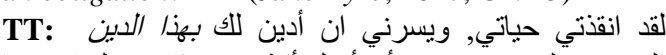

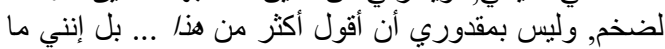

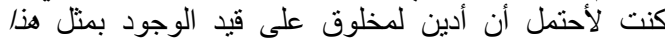
(Morad, Volume 2, p.67)

[Gloss: You have saved my life, and I am pleased to owe you this huge debt, and I cannot say more than this. I never thought that I would owe a person in the world this obligation]

8. ST: He looked at me, then stood up.

"I'm going on."

"What's the trouble?"

"-- the war."

"What's wrong with your leg?" (A Farewell to Arms, 1929, Ch. 7)

TT: ... إنها هذه الحرب (Nasim, p.32)

[Gloss: It is this war]

In Example (6), after Mr. Rochester arrives at Thornfield with some guests and gets busy with them, he asks Jane why she has not caught up with him in the meanwhile. Assuming that Mr. Rochester is the one who is supposed to ask after her, she thought of retorting "the question" on him. The definite article "the" in "the question" is shifted into the proximal "this", which in this context can bring the referent "the question" closer to Jane in the emotional space and hence may express a greater emotional engagement or reaction on her part.

This pattern of shift affects not only the narrator but also the other speaking characters. In Example (7), 
after a fire is set to Mr. Rochester's room and Jane poured water on him to save his life, she tries to leave his room but he catches her hand and insists on thanking her. The translation inserts the proximal "this" in "I cannot say more than this" and also shifts the indefinite articles "a" and "an" into "this" in "a debt" and "an obligation", which exalts the emotional participation and attachment on the part of the character, Mr. Rochester. In (8), after returning from the post, Henry sees a fellow American soldier walking with a limp and asks him about the cause of his trouble, and he replies that it is "the war". Changing "the war" into "this war" in translation can also intensify the feelings and emotions of the character (the soldier) in the event.

\section{DISCUSSION}

The data show that there is a tendency in the translated narrative to lexicalize more spatio-temporal relationships and functions than the original does. There is an orientation to encode extra explicit place and time settings, resulting in a more deictically-marked narrative at face value. There is an adjustment in "the deictic perspective" of the original (Richardson, 1998, p. 127); it reveals more verbal pointing and further spatiotemporal characteristics that result in readers creating more or new "mentally constructed world of the text" (Stockwell, 2002, p. 47). This can also point to an increased gestural reference in the translated text: a greater "identification of the referent by means of some bodily gesture on the part of the speaker" (Lyons, 2005, p. 303).

The result is an increased deictic anchorage, which emphasizes the position of not only the main narrators (i.e., Jane and Henry) but also other main speaking characters (e.g., Mr. Rochester in Jane Eyre and Catherine or Rinaldi in A Farewell to Arms). When comparing the data, the study does not find any significant preference in the shifts to center around the main narrator or any other certain character(s). One may suggest here that the translators may have been unaware of which character or whose position is being emphasized by the addition of deixis, or that the translators may have added these deictics randomly or unconsciously.

The tendency to add further spatial and temporal knowledge, which is often carried implicitly in the original because it is retrievable the story context (Vinay \& Darbelnet, 1995, p. 342), involves a process of "amplification from implicit to explicit status" (Nida 1964, p. 228), that can enhance the text's communicability and fluency (Venuti, 1995). This can also reflect a tendency in translation to "disambiguate" or simplify the original (Toury, 2012, p. 306), which can also be considered an instance of explicitation (Blum-Kulka, 2004), a universal feature of the translational language.

The data also point to an orientation towards reducing distance [-distance] and using a more approximated spatio-temporal viewpoint in translation.
Based on the apparent context, this shift involves both (i) physical distance, such as in the replacement of "that house" with "this house" in Example (3) and emotional distance (Levinson 1983, p. 81), such as in the replacement of "a debt" with "this debt" in Example (7). The comparison of data reveals that 344 shifts (about $64 \%$ of total approximating shifts) can involve emotional distance, while 194 shifts (about 36\% of approximating shifts) can involve physical distance. This points to a tendency towards a greater use of emphatic or secondary deixis (Lyons, 1977, 2005) and a greater empathy or "immersion" on the part of both the narrator and characters (Toolan, 2016, pp. 37-38), allowing for a more personal view of story events and a more subjective internal narrative (Uspensky, 1973, p. 81).

If we assume that Ernest Hemingway's style in the story is often understated, spare and without emotion (Bloom, 2009, p.31), the approximating shift here will mean a move towards a style that is more expressive and emotive. The minimalist and insufficientlyemotional writing style of Hemingway seems to be normalized or standardized in the translated text (Toury, 2012). This move towards a greater expressive style might be quite normal in fiction translation as the conventional function of a fictional text is normally to "express" feelings and emotions (Reiss, 2004). The style of Jane Eyre is however "feverish in its intensity" (Milton, 1984, p. 34) and highly charged with the narrator's personal feelings and emotions (Bloom, 2006, pp. 18-19). The approximating trend here may then point to higher intensity and more emotive language in the translated text, which, unlike A Farewell to Arms, can emphasize the stylistic characteristics of the original.

What can be clearly noticed is that there is a shift towards displaying more emotions on the part of the narrator and characters. This can be arguably taken as a move to a more marked perspective (point of view) or less ambiguous voices in the translated text (see Klinger, 2015, pp. 68-73). Such pattern may be an indicator of the translator's dislike for ambiguous narrative perspectives. The increased empathy in translation may also increase the target readers' projection and immersion into the story-world and enhance their emotional involvement with the narrator and characters (Klinger, 2014, p. 168, see Gavins, 2007, pp. 38-41).

The two original stories employ a highly-engaged narrator and invite the reader's active participation and emotional involvement (Bloom, 2006, 2009). The vivid and immediate reporting of events in A Farewell to Arms allows readers to share immediate visual experience with the narrator. The Bildungsroman style of Jane Eyre also guides the reader step by step through the narrator's journey of emotional and cognitive development. The shift towards a greater empathy should mean in this context a move towards a more dynamic interaction with the text and hence a more 
participating reader in translation, a move that seems to go with the style of the original (Boase-Beier, 2014).

Before any attempt to describe the underlying reasons behind the trends of shifts here, it should be noted that it is often quite difficult to rely on only textual data to confidently link a translational shift to a certain deliberate strategy on the translator's part (Mason, 2000, p. 17). Textual data may allow us however to speak of translation processes that bring about the shift, rather than any specific intentions or motivations on the translator's part. As suggested before, the addition of spatial and temporal knowledge (e.g., "here", "this story", "now" or "at this moment") involves an explicitation of the certain deictic information. This information is often carried implicitly in the source language and its explicitation in translation should indicate an interpretive effort made by the translator (Blum-Kulka, 2004, p. 300). Take as an example Rochester's utterance in Example (1) "He is not resident, then?", which is translated as "then he does not reside here?". The translation adds the deictic "here", which refers to Thornfield, which involves information that can be accessed only from the context and only by the process of interpretation. This shift is inevitable in literary translation if we accept that "interpretation of the source" is an inescapable stage in the creation of a literary translation and that each act of reading a text is per se an act of interpretation (Levý, 2011, pp. 38-39).

So, the shifts in this study may be regarded as textual traces of the translators' (intentional or intentional) attempts to reset the time and place coordinates of the original context, where the translator, after interpretation, constantly tries to focus the lens of the camera (Goethals \& De Wilde, 2009, p. 785). In other words, they can be nothing more than the traces the translator leaves behind after the retelling and recontextualization of the original story, which may here involve insertion of new spatial and temporal coordinates. When a translator adds deictic elements like "now", "here" and "this night" or changes "the event" into "this event" in a translation, it is nothing more than a translator trying to reset the spatio-temporal dimensions while re-creating the original story for the new reader.

It may be easy to give such a justification to such patterns as the addition of elements like "here", "now", or "that day". But what could be more difficult is to explain why a translation opts for a more approximated point of view and more emphasized emotions. The study however suggests here that the increased spatiotemporal proximity and intensified empathy may reflect the literary translators' mental representation of the story after their conception of its ideas and realities. The perception of the story and the building of its image in the translators' minds may be reflected in translation choices. Unlike ordinary readers, translators may have to express their "conception in another language, which normally leads to "a second verbal materialisation of the semantic values of the work" (Levý, 2011, p. 28; emphasis added). For instance, expressions like "the question", "a debt", "an obligation" and "the war" in Examples (6), (7) and (8) could have been easily replaced with their formal equivalent, but the translator here opts for the forms "this question", "this obligation" and "this war", which display greater emotional proximity and empathy (see "non-obligatory" shifts, Toury, 2012, p. 80). The greater empathy expressed here could be a reflection of the translator's (conscious or subconscious) creative efforts to reconstruct the attitudes and emotions of the narrator and characters in the translated text.

The study finds that the approximating shifts occur most often in contexts that imply, either explicitly or implicitly, feelings of emotional empathy on the part of the narrator and characters (see Klinger, 2015, pp. 6465 ), such as when a soldier with a broken leg is being asked by Henry about the cause of his injury, or when Jane saves Mr. Rochester's life while he is sleeping and then she unexpectedly decides to leave the room before he shows his gratitude to her (see Example 7 and 8). The use of approximated forms that emphasize this emotional empathy (e.g., "this war" and "this debt") can express here a translator's mental image that conforms to the original voice or perspective. This in other words indicates the translator's attempts to speak for the original narrator and characters, supporting the view that translators often speak for the original writer, and hence may have "no independent stylistic voice" (Jones, 2009, pp. 153-154).

\section{CONCLUSION}

The deictic shifts in this study manifest an orientation towards encoding more spatio-temporal knowledge, which indicates a more accentuated or marked deictic anchorage and focalization in the translated narrative. This confirms the findings of Abualadas (2015), that reveal a shift towards increasing deictic anchorage, and contradicts those of Bosseaux (2007), which point to losing focalization and anchorage points in translation. The increased deictic focalization has brought about a greater spatio-temporal proximity, which is suggestive of greater involvement and empathy on the part of the narrator and characters in the translated narrative. There is a shift towards a narrative with more marked or emphasized point of view and increased narratorial subjectivity. This finding seems to contradict the results of Mason and Şerban (2003), which indicate a shift towards a more distanced and objective point of view. The study here confirms the results of Abualadas (2015), which point to a more approximated point of view and an increased involvement and subjectivity on the part of the narrator, but it further finds that both the narrator and characters in the two stories can be similarly affected by these patterns of shift, with no clear orientation towards the narrator or any particular character(s).

The study also finds that the approximating shift results mainly from a change in emphatic deixis, where 
emotional distance is more adjusted or affected than physical distance. This means that emotions and feelings may be given priority over physical space dimensions, allowing for more subjective viewpoints and more marked psychological and emotional perspectives in a translated narrative. In other words, there is a shift in translation towards clearer boundaries between different voices and less ambiguous perspectives. The shift here does not confirm the findings of some earlier studies that point to a more objective viewpoint and less empathy in translation (e.g., Jonasson, 2001; Mason and Şerban, 2003).

The shifts in viewpoints in the present study may affect the original style in several ways. The approximating shift intensifies the emotional empathy in the two stories. In translations of such a story written with highly emotive and expressive style as Jane Eyre, this greater empathy can reflect an adoption of the original author's perspective in translation. But it moves in the opposite direction of the original style in the translations of Hemingway's story, as he uses an understated style which often leaves it to the reader to untangle people's emotions and feelings in the events. If we consider that a literary text conventionally expresses thoughts from a subjective point of view and leaves an emotional and psychological effect (Landers, 2001, p. 27), the shift into a greater empathy and subjectivity will constitute a shift into a more habitual and normalized style in translation (Toury, 2012).

Unlike Abualadas' study (2015), which relates deictic shifts to certain motivations on the part of translators, such as their preference for explicitation to meet the target reader's expectations, this study argues that, with textual data, it is safer to relate deictic shifts to an interpretative process that consists in reformulating the spatio-temporal settings of the original discourse based on the translator's mental apprehension and representation of the story. This seems to support Goethals and De Wilde's (2009) hypothesis that deictic shifts often result from the translational interpretation. But unlike their study, in which the translational interpretative processes do not suggest any approximating or distancing patterns in the original point of view, the interpretative processes in the present study have favoured, or led to, a more approximated one. This suggests that the interference of interpretation can sometimes be systematic in that it adopts, or recreates, the psychological perspective of the original. Finally, future studies may explore the ways in which stylistic variations or preferences in using spatial and temporal deixis in English and Arabic fictional texts may play a role in the deictic shifts.

\section{REFRENCES}

Abualadas, O. (2015). A Linguistically-oriented approach to literary translation: A comparative pragmatic study of three Arabic renditions of the English novel Wuthering Heights (Unpublished doctoral dissertation). University of Leeds, Leeds, UK.

Abualadas, O. (2018). Translation shifts in spatial and temporal deixis: A trend towards a more subjective narrative mood in fiction translation. Arab World English Journal for Translation \& Literary Studies, 2(1), 182-196. doi: 10.24093/awejtls/vol2no1.14

Baalbaki, M. (Trans.). (2006a). A Farewell to Arms. Beirut: Dar-Alqalam.

Baalbaki, M. (Trans.). (2006b). Jane Eyre. Cairo: Modern Arab Establishment.

Berridge, H. (1984). Barron's book notes: Ernest Hemingway's A Farewell to Arms. New York: Barron's Educational Series.

Bloom, H. (2006). Bloom's guides: Charlotte Brontë's Jane Eyre. New York: Infobase Publishing.

Bloom, H. (2009). Ernest Hemingway's A Farewell to Arms. New York: Infobase Publishing.

Blum-Kulka, S. (2004). Shifts of cohesion and coherence in translation. In L. Venuti (Ed.), The translation studies reader (pp. 298-313). London and New York: Routledge.

Boase-Beier, J. (2014). Stylistics and translation. In M. Burke (Ed.), The Routledge handbook of stylistics (pp. 393-407). London and New York: Routledge.

Bosseaux, C. (2007). How does it feel? Point of view in translation: The case of Virginia Woolf into French. Amsterdam: Rodopi.

Fowler, R. (1996). Linguistic criticism ( $2^{\text {nd }}$ ed). Oxford: Oxford University Press.

Gavins, J. (2007). Text world theory: An introduction. Edinburgh: Edinburgh University Press.

Goethals, P. (2007). Corpus-driven hypothesis generation in translation studies, contrastive linguistics and text linguistics: A case study of demonstratives in Spanish and Dutch parallel texts. Belgian Journal of Linguistics, 21, 87-104.

Goethals, P. \& De Wilde, J. (2009). Deictic center shifts in literary translation: The Spanish translation of Nooteboom's Het Volgende Verhaal. Meta, 54(4), 770-794. doi: 10.7202/038903ar

Halliday, M. \& Matthiessen, C. (2004). An introduction to functional grammar ( $\left.3^{\text {rd }} \mathrm{ed}\right)$. London: Edward Arnold.

Jones, F. (2009). Literary translation. In M. Baker, \& G. Saldanha (Eds.), Routledge encyclopedia of translation studies ( $2^{\text {nd }}$ ed) (pp. 152-57). London: Routledge.

Klaudy, K. (2009). Explicitation. In M. Baker, \& G. Saldanha (Eds.), Routledge encyclopedia of translation studies ( $2^{\text {nd }}$ ed) (pp. 80-84). London: Routledge.

Klinger, S. (2014). Translating the narrator. In J. BoaseBeier, A. Fawcett \& P. Wilson (Eds.), Literary translation redrawing the boundaries (pp. 168181). UK: Macmillan.

Klinger, S. (2015). Translation and hybridity: Constructing world-view. London and New York: Routledge. 
Landers, C. (2001). Literary translation: A practical guide. Clevedon: Multilingual Matters.

Levinson, S. (1983). Pragmatics. Cambridge: Cambridge University Press.

Levinson, S. (2006). Deixis. In L. Horn \& G. Ward (Eds.), The handbook of pragmatics (pp. 97-121). Oxford: Blackwell Publishing.

Levý, J. (2011). The art of translation. (P. Corness, Trans.) Amsterdam and Philadelphia: John Benjamins.

Lyons, J. (1977). Deixis, space and time. In Semantics, (Ch. 15, Vol. 2, pp. 636-724). Cambridge: Cambridge University Press.

Lyons, J. (2005). Linguistic semantics. Cambridge: Cambridge University Press.

Mason, I. (2000). Audience design in translation. The Translator, 6(1), 1-22. doi: 10.1080/13556509.2000.10799053

Mason, I., \& Şerban, A. (2003). Deixis as an interactive Feature in literary translations from Romanian into English. Target, 15(2), 269-294. doi: 10.1075/target.15.2.04mas

Milton, J. (1984). Barron's book notes: Charlotte Brontë's Jane Eyre. New York: Barron's Educational Series.

Morad, H. (Trans.). (1998). Jane Eyre. Beirut: DarElilm Li-Almalayin.

Nasim, R. (Trans.). (1981). A farewell to arms. Beirut: Dar-Elilm Li-Almalayin.

Nida, E. (1964). Toward a science of translating: With special reference to principles and procedures involved in Bible translating. Leiden: E.J. Brill.

Pápai, V. (2004). Explicitation: A universal of translated text? In A. Mauranenand \& P. Kujamäki (Eds.), Translation universals: Do they exist? (pp. 143164). Amsterdam and Philadelphia: John Benjamins.

Reiss, K. (2004). Type, kind and individuality of text: Decision making in translation. In L. Venuti (Ed.),
The translation studies reader (pp. 168-79). London and New York: Routledge.

Richardson, B. (1998). Deictic features and the translator. In L. Hickey (Ed.), The pragmatics of translation (pp. 124-142). Multilingual Matters: Clevedon.

Saldanha, G., \& O’Brien, S. (2013). Research methodologies in translation studies. Manchester: St. Jerome.

Segal, E. (2009). A cognitive-phenomenological theory of fictional narrative. In J. Duchan, G. Bruder \& L. Hewitt (Eds.), Deixis in narrative: A cognitive science perspective (pp. 61-78). London and New York: Routledge.

Simpson, P. (1993). Language, ideology, and point of view. London and New York: Routledge.

Simpson, P. (2004). Stylistics: A resource book for students. London and New York: Routledge.

Stockwell, P. (2002). Cognitive poetics: An introduction. London and New York: Routledge.

Toolan, M. (1990). The Stylistics of fiction: A literary linguistic approach. London: Routledge.

Toolan, M. (2016). Making sense of narrative text situation, repetition, and picturing in the reading of short stories. London and New York: Routledge.

Toury, G. (2012). Descriptive translation studies-and beyond (revised edition). Amsterdam and Philadelphia: John Benjamins.

Uspensky, B. (1973). A Poetics of composition: the structure of the artistic text and typology of a compositional form. Berkeley and Los Angeles: University of California Press.

Venuti, L. (1995). The translator's invisibility: History of translation. London: Routledge.

Vinay, J-P., \& Darbelnet, J. (1995). Comparative stylistics of French and English: A methodology for translation. Amsterdam and Philadelphia: John Benjamins. 